\title{
PRESIDENTIAL ELECTIONS: Centrality, Context, and Implications*
}

\section{Olavo Brasil de Lima Junior}

This article will take what, at first, will seem like a less than conventional approach, particularly for analysts avid for numbers. The reason for this is that the numbers are insufficient and unreliable.

The basic aim of this article is to prove that it was the confluence of certain demographic, social, economic, and political factors, which began in 1960 that nationalized elections, and integrated and democratized Brazil. Increased urbanization ensured that the election of the president did not depend only on rural political forces, but on an infinity of possible combinations of rural and urban forces. A presidential candidate can no longer rely on specific and numerically forceful segments of society to guarantee his success; he/she needs more expanded social bases.

My argument will be constructed step by step throughout this article. At first, I shall attempt to prove that the electoral market expanded on all territorial fronts, particularly as a consequence of the urbanization and growth of the voting popula-

* Published originally in Revista Brasileira de Ciências Sociais, volume 14, n. 40, June 1999, pp. 11-30.

Translated by Alison Barnes and revised by Argelina Figueiredo and Renato Boschi. tion, a figure systematically greater than population figures. In addition, the progressive fall of voting barriers, such as income, class, age, and education, democratized voting, and diversified the social composition of voters. Not all these improvements represented equal benefits for all regions and all states; frequently their impact on the increase in voters differed according to context.

Nationalization of the vote, defined by the indicators described above, is a part of the political integration of society. An election of the proportions of a presidential election, in association with the social complexity of the voting population, requires that the political message and the claim of the candidate wishing to maximize the vote must be very broad. This is essential to avoid any manifestations, during the campaign, of potential conflict threatening to fragment support of the candidate to a degree that places the formation of a national majority, as described above, at risk.

The first part of the article examines a national reluctance to acknowledge the Presidency as Brazil's supreme position. This is due to the people's troublesome and conflicted relationship with a federative republic that has yet to be seen as an institution, which did not arise from a unanimous 
agreement between the states, and which is not viewed as a permanent political factor.

The second analytical part discusses, operationalizes, and explains Brazil's political integration, based on the results of the direct presidential elections of 1960, 1989, 1994, and 1998. I have availed myself of demographic, social, and political indicators to reach my conclusions on the nationalization of the presidential elections since the 1960 presidential election.

Lastly, in the third part, I have carried out a careful evaluation of the circumstances surrounding the more recent presidential elections, and have compared the candidates' social bases in the 1994 and 1998 election campaigns.

\section{From rulers to presidents}

Some time ago, I read the Livro de Posse dos Presidentes da República (book where the inauguration of Brazilian presidents is recorded), which was restored for the Centennial of the Republic Celebrations by the Fundação Casa de Rui Barbosa and published in 1991 in a facsimile edition, jointly by this same Foundation and the Federal Senate. This book inspired me to re-examine Brazil's political history, based on an analysis of one of the few more permanent but barely institutionalized aspects of Brazilian semi-constitutional life: the presidential elections and their implications.

Brazilian Republic has had 38 presidents, some directly elected and the majority indirectly, two military governments, and seven constitutions, advances and deteriorations in the democratic process, represented by differing political regimes. The first period (1989-1930) was that of the provisional government headed by marshall Deodoro da Fonseca and 12 presidents. After the National Constitution Convention proclaimed the 1891 Constitution, the former became the National Congress and elected Deodoro da Fonseca and Floriano Peixoto, as president and vice-president, respectively, despite the unequivocal preference of Congress members for the non-military candidate, Prudente de Morais. In November 1891, Deodoro closed down Congress, resigned, and handed over the government to his successor, Floriano Peixoto, who concluded the Republic's first presidential mandate.

All three succeeding and non-military presidents fulfilled their terms of office. Afonso Pena, who died in 1909, did not resume his second term, as then permitted, since he died before taking office. He was succeeded by his vice-president Nilo Peçanha who fulfilled his term of office. From 1910 through 1930, we had six presidents, all of whom also fulfilled their terms of office. This was a period of upheaval caused by a variety of political movements. The most politically significant of these movements were those of the twenties, with their slogan of "representation and justice for all". This period also became notorious for its contempt for the Constitution: federal intervention in the states, civil and military coups, and minimal participation of the voting public. This participation was doubly fraudulent, firstly due to the use of electoral lists of questionable reliability (ex officio) and, secondly the requirement that the election results had to be "recognized" by the House of Representatives, by that arbitrary mechanism known in Portuguese as bico de pena, best described as unilateral decree.

The second republican period (known as the Second Republic) began after the 1930 Revolution that broke out allegedly due to the nation's refusal to accept the official results of the 1930 presidential elections. The Second Republic was inaugurated by a government coalition that, on October 3 swore in Getúlio Vargas (Lima Junior et al., 1991, p. 138) who governed from 1930 to 1934 as provisional president. From 1934 to 1937 he was the legitimate president of Brazil, having been indirectly elected by Congress for a four-year mandate. This mandate was abruptly terminated by the president's coup in 1937, when the so-called Estado Novo was inaugurated and continued uninterruptedly until 1945.

Ten presidents governed throughout the Third Republic (1945-1965). The first was the president of the Federal Supreme Court, José Linhares, who took office on October 29, 1945, shortly after Vargas was deposed. Only two presidents, Eurico Gaspar Dutra (1945-1950) and Juscelino Kubitschek de Oliveira (1955-1960), the latter only 
by overcoming many obstacles, succeeded in fulfilling their full terms of office. When Vargas, reelected in 1950, committed suicide, he was succeeded by his vice-president, Café Filho.

When Juscelino Kubitschek was elected in 1955, he was unable to be sworn in due to his election being challenged by the right wing opposition. The reactionary forces prevented him from taking office, and installed the president of the House of Representatives, Carlos Luz, as successor to the vice-president Café Filho. Café Filho, known for his loyalty to Kubitschek and to the Constitution was forced to take a leave of absence. Later, when he attempted to return to power, he was deposed and a second military coup installed the then vicepresident of the Senate, Nereu Ramos as president. However, thanks to a counter military uprising, the legitimately elected president, Juscelino Kubitschek, finally took office. The last president elected during the Third Republic, Jânio Quadros, took office in 1961, but resigned in August of the same year, claiming that it was impossible to govern due to "excess" opposition and other alleged impossible demands imposed on him.

In the midst of a serious political crisis, the Presidency was temporarily taken over by the president of the House of Representatives, Ranieri Mazzilli, since vice-president João Goulart was out of the country. On his return, Goulart was prevented from taking office by the military and members of the right wing opposition. Only after lengthy and equivocal negotiations between the politicians and the military was he sworn in as president. One condition of these negotiations required him to sign a "statement of commitment" in which he agreed to uphold the Constitution even after the coup that represented Congress' approval (253 votes in favor and 55 votes against) of a "constitutional amendment" establishing the parliamentary system of government in Brazil (Amendment 4, of September 2, 1961) (Lima Junior et al., 1991, p. 246).

Although the reliability of the Livro de Posse is unquestionable - there is no record as to whether the circumstances were irregular, i.e., when "the inauguration" did not strictly complied with the rules and the procedures established by the Consti- tution then in force - it records the unprecedented "statement of commitment", signed by João Goulart, and all the other procedures related to the installation of the parliamentary system of government and the return to the presidential system (Lima Junior et al., 1991, pp. 221-256). The right wing faction based its unconcealed opposition to Goulart on the allegation that he intended to radically amend the 1946 Constitution, the very document that protected his right to the Presiden$\mathrm{cy}$, without the need to resort to legal violations to which he and the nation were subjected.

Three parliamentary cabinets then followed. The return to the presidential system came about based on the plebiscite decision of January 6, 1963. This consisted of 9,457,488 votes in favor and 2,073,582 against. On March 31(or April 1?), 1964, the army deposed president Goulart and, immediately thereafter, on April 2, Congress declared the office vacant and swore in the president of the House of Representatives and second in line of succession, Ranieri Mazzilli. The inauguration of Mazzilli was not recorded in the Livro de Posse.

The military dictatorship which was the Fourth Republic (1964-1985), began with two indirectly elected military presidents, followed by a junta comprised of three military commanders, after which there were a further three military presidents, also indirectly elected. The indirect election of Tancredo Neves and his vice-president, José Sarney, heralded the conclusion of the political domination imposed by the armed forces, in association with the more conservative forces of the country, and the "New Republic" was born.

In 1989, a president was once again elected by the people. This was Fernando Collor de Mello, who also did not complete his term of office because he was constitutionally impeached, as a result of his many administrative misdemeanors. His political rights were also suspended by Congress. His vice-president, Itamar Franco, completed his predecessor's term of office and was succeeded by Fernando Henrique Cardoso, elected president in 1994 and re-elected in 1998.

From 1889, the year of the Proclamation of the Republic to 1998, the year in which our current president was elected, 109 years have elapsed, i.e., 
1,308 months. If we add up all past incumbents to the Presidency (individually or collectively, legitimately or illegitimately), we arrive at a total of 40 holders of this title, excluding Afonso Pena, Rodrigues Alves (second term), and Tancredo Neves, who died before they could formally take office. This shows an average length of time in office of little more than 32 months. If we exclude the Vargas era (1930 to 1945, or 178 months), we arrive at an average of 28 months for all 40 holders of this office. It is important to remember that the duration of the Brazilian presidential term of office has varied from four to six years.

In the United States of America, where reelection is permitted, to date, there have been 42 presidents. The overwhelming majority of US presidents campaigned for and achieved a second term of office. In this case, the data shown in Table 1 break a few taboos with respect to the duration of constitutions and their relationship with democracy. It is a common misconception that democracies have stable constitutions and that this very stability is an integral part of the democracy itself. However, to quote Lane (1996, p. 198), the facts do not bear out this theory:

All constitutions tend to be short-lived, not only the democratic ones. Regardless of the basis on which their duration is measured, the conclusion does not vary: constitutions are transient [...] The majority survive for one or two decades, or even less, the exceptions being those of the USA and Oceania.

I believe the central issue to be the nature of the constitutional change; arguments for and against their stability are secondary. If the change, seen in the context of a democratic theory alien to the Constitution, is of a democratizing nature, instability is less important. If, however, it does not democratize, it is preferable to maintain the current stability.

Thus, under the aegis of an oligarchic republic, our republican instability is characterized by minimal institutionalization of regulations and procedures, total lack of respect for the opposition, which was almost non-existent and, most of the time silent or exterminated, and by minimal voting participation. To summarize, this is what Dahl (1997) defined as a hegemonic oligarchy that nevertheless was heavily pressured to permit, at least some political "competition", despite such competition being palpable, controlled, and its results regularly falsified by the ruling powers.

The 1930 Republic, due to its origins, was all too uncomfortably aware of the overwhelming call for democratic and moral government. Thus, it suspended the constitutional order and subjugated

Table 1

Duration of Constitutions

\begin{tabular}{lcccc}
\hline Regions & Countries & Average year of introduction & Earliest year & Most recent year \\
\hline Western Europe & $(15)$ & 1943 & 1814 & 1993 \\
Eastern Europe & $(19)$ & 1985 & 1922 & 1993 \\
North America & $(2)$ & 1885 & 1789 & 1982 \\
Central America & $(12)$ & 1970 & 1917 & 1987 \\
Latin America* & $(10)$ & 1967 & 1853 & 1993 \\
North Africa & $(7)$ & 1980 & 1959 & 1992 \\
Sub-Sahara Africa & $(36)$ & 1984 & 1960 & 1993 \\
Asia Minor & $(13)$ & 1968 & 1921 & 1991 \\
Greater Asia & $(26)$ & 1977 & 1945 & 1993 \\
Oceania & $(3)$ & & 1852 & 1975
\end{tabular}

*In the last column, the "most recent" year is 1993, and appears four times. There is no indication of the last year of the survey. In the case of Brazil, the researcher is undoubtedly using the year of the 1988 Constitution.

Source: Lane (1996, p. 198). 
Brazil with a civil dictatorship which, among its few merits, was responsible for establishing public administration of Brazil (Lima Junior, 1998) and for taking the first steps towards the country's industrialization. As a political regime, on the democratic scale, it ranked zero.

The subsequent period (1945-1964) was marked by its substantial political incorporation, particularly of the urban segments, a fair degree of institutional democratization, despite its instability and the difficulty encountered by the élite in acknowledging the legitimacy of the institutions, and in particular, election results. The country was stumbling, with many difficulties and frequent retreats, in the direction of Dahlsian polyarchy. But, still, political democracy did not fully manifest itself.

The widening involvement in elections did not halt during these periods of military government (1964-1985), which grew from a military intervention to remove a supposedly untrustworthy president, to a violent military dictatorship operating behind a façade of political and voting involvement, both basically superfluous and aimed at legalizing the military regime. The democratic political institutionalism that had advanced haltingly through the fifties and sixties was savagely destroyed.

The second attempt at redemocratizing Brazil began with the transfer of power to the civil sector and with the promulgation of the 1988 Constitution, seen at the time as being apposite and democratic. Liberal representative democratic institutions began to return and/or were implemented for the first time, including the voting participation of all levels of society. Significant advances were made if we compare this re-introduction of democracy with the events of 1945 .

Unfortunate circumstances, totally independent of any collective action, began to produce negative signals immediately upon the transfer of power from the military to the civil segment. Firstly, the president indirectly elected in 1985, Tancredo Neves, died before being sworn in and his vicepresident, José Sarney, took office. Subsequently, in 1992, the first president elected by direct vote since the end of the military dictatorship, Fernando Collor de Mello, was impeached by Congress and substituted by his vice-president, Itamar Franco.

For a variety of reasons, the instability associated with the Presidency seems to be a constant in Brazilian public life: of the country's democratically elected presidents, three died before taking office, one was brutally prevented from so doing and only succeeded in being sworn in through a counter military coup, one committed suicide while in office, and two were removed from office before fulfilling their terms. I emphasize here the instability of the presidential office, for which there are many reasons, and not of the presidential system of government, an aspect I shall not comment on here.

The institutional framework established in 1988 with so much difficulty has frequently been challenged, particularly as from the second year of the Cardoso government, through changes leading to constitutional amendments and to infraconstitutional legislation. Independently of any value judgments in the context of ethics, politics, or the economy, and of any other justifications, the instability of institutions in general continues. This instability has at times included the system of government, the political parties, and the voting system, due to too frequent changes of regulations, reminding us of the casuistry of the military governors. As a general rule, the political justification of these changes has been to break with the past and outdated "Estado Novo" and to replace it with a "New State" (Lima Junior, 1998).

This brief retrospective, mostly inspired by the Livro de Posse of Brazilian presidents, shows that Brazil has had many constitutions and cartas outorgadas: 1891, 1934, 1937, 1946, 1967, 1969 , and 1988. On average, they remain in force for 14.7 years. This average of 14 years relates to the republican documents, of which only three were truly democratic constitutions, i.e., prepared by bodies specifically elected to compose, discuss, and approve a new charter. Thus, as a rule, this instability results from disrespect for the current Constitution, provoked by social forces alien to the legally constituted powers.

The Brazilian political system is characterized by democratic advances and oligarchic and dictatorial retrogression. At no time did the essential 
elements of liberal representative democracy prevail. These are a high degree of involvement by the majority of the social sectors; stable regulations; honest political competition; and the stability of the macro political players - the political parties.

The extension of voting franchises has been the sole permanent feature of our political organization, even when they had little significance due to their political irrelevance. The last constraints were removed quite recently with the voluntary inclusion into the electoral process of the illiterate and those of over 16 but still under 18 years of age.

An indication of the significance of the Old Republic elections is the fact that, in 1894, only about $2 \%$ of the population went to the polls; in 1922 , the number of voters had increased to 833,270 , approximately $2.9 \%$ of the population; in 1930 , the then $1,890,805$ voters represented $5.6 \%$ of the population. These are very small percentages when compared with the most recent election data (Carvalho, 1990, p. 17).

\section{Nationalization of the presidential elections}

Brazilian territorial integration under a single and unchallengeable government, as is the case today, took some hundreds of years. The process was finally concluded at the beginning of the twentieth century, thanks to the diplomatic efforts of Rio Branco. The same cannot be said of the integration of the political representation of the population, which only occurred at the end of the Estado Novo. In this section, I shall cover some of the indicators of the nationalization of Brazilian public life. I shall attempt to measure and evaluate the integration of society from the political and electoral participation point of view, based on the presidential elections.

The size, the growth, and the distribution of the electorate over the Brazilian political space, and the relative contribution of each of the units of which this scene is comprised, reveal the nationalization of politics. The political integration indicator I shall use is the social composition of the electorate that votes for a president since I would be able to evaluate if the social heterogeneity that characterizes the nation is reflected in the presidential elections. The less any segment of society is excluded from the victorious electorate, the more integrated the country's politics and the more democratic its elections.

To the extent that the electorate is related to the population, and the greater the enfranchisement, the greater the electorate, the geographic distribution of the electorate in a presidential election is an excellent indicator of Brazil's political and territorial integration. The more disperse in the political space the electorate that vote for the victorious presidential candidate, the more democratic the election.

Table 2

Brazilian Electorate by Region in the Presidential Elections (in \%)

\begin{tabular}{|c|c|c|c|c|}
\hline Regions & 1945 & 1950 & 1955 & 1960 \\
\hline North & 2.75 & 3.32 & 3.49 & 2.91 \\
\hline Northeast & 24.93 & 29.40 & 28.47 & 24.78 \\
\hline Southeast & 53.27 & 49.13 & 48.07 & 49.70 \\
\hline South & 16.50 & 15.08 & 16.30 & 18.50 \\
\hline Central West & 2.53 & 3.05 & 3.65 & 4.00 \\
\hline \multicolumn{5}{|l|}{ Total } \\
\hline (in thousands) & 7.459 & 11.455 & 15.243 & 15.543 \\
\hline Regions & \multicolumn{2}{|l|}{1989} & 1994 & 1998 \\
\hline North & 5.39 & \multicolumn{2}{|c|}{6.13} & 6.36 \\
\hline Northeast & 26.23 & \multicolumn{2}{|c|}{26.84} & 25.91 \\
\hline Southeast & 45.74 & \multicolumn{2}{|c|}{44.51} & 45.31 \\
\hline South & 16.42 & \multicolumn{2}{|c|}{16.04} & 15.81 \\
\hline Central West & \multirow[t]{2}{*}{6.20} & \multirow{2}{*}{\multicolumn{2}{|c|}{6.46}} & 6.59 \\
\hline Total & & & & \\
\hline (in thousands) & 82.056 & \multicolumn{2}{|c|}{94.743} & 6.053 \\
\hline
\end{tabular}

Sources: Santos (1987), for the 1945 to 1960 data; Nicolau (1998), for 1989 and 1994; and TSE, IT Secretariat, Internet, for 1998. The last data show some inconsistencies: when all the numbers are added, the total obtained does not agree with the total resulting from the sum of the votes registered with the abstentions. Despite these discrepancies, the value of this interpretation is not jeopardized, since the figures in question are low. This comment applies to all data relating to 1998 shown in the remaining charts.

This is precisely the trend revealed in the data in Table 2. The participation of the South-Eastern Region, still Brazil's largest electoral college, has been dropping systematically to the point where the involvement of the Northern and CentralWestern regions that, until quite recently, were 
viewed as demographic and economic "frontier" territory, is growing. It should be borne in mind also that the number of states has also increased in these two regions, and consequently participation in other elections that did not exist before (state governments, state assemblies, and senators) has also increased. In the Northeast, relative involvement has varied little from election to election, and remained relatively stable at $25 \%$ in the most recent elections. The situation is similar in the Southern Region.

It is worth noting that the social processes responsible for the alterations pointed out differ in time and in political space; even some national processes such as, for example, the extending of franchises, affect different states and regions differently.

The 1945 regime represented a significant step forward from the point of view of its democratic content (Lima Junior, 1997) as compared with earlier periods. Below, I discuss the results of the presidential elections, evaluate the involvement of the electorate, their political significance, and distribution throughout the country, in order to locate a point of inflection that defines the nationalization of political life. The lack of reliable social data on voters prevents us from evaluating the long-term composition of the electorate, a major indicator in the nationalization of presidential elections. However, the time at which the presidential elections became clearly nationalized can be analyzed based on the regional distribution of the votes and their sources according to the size of the respective cities (Table 3). Here I shall examine the relative weight of the rural:urban ratio.

These points were first raised by Souza (1976), examined in detail by Lavareda (1991), and recently re-analyzed by Lima Junior (1995). In his reflections on the 1960 presidential elections, won by Jânio Quadros and João Goulart, candidates of different parties and who broke the traditional PSD-PTB alliance, which had hitherto always been victorious, Souza points out that the presidential election had less dramatically differentiated the electorate based on the sectors of society. Furthermore, it was no longer possible to elect a president based only on the results of the states with the largest electoral colleges. It was now vital to win over small state voters. Lastly, the rural:urban ratio was hardly decisive, regardless of there being differences, in this context, between the various candidates. Winning the votes of a potentially mobilizable electorate, better distributed through the states and regions, became one of the essential conditions to a presidential election victory.

Table 3

Source of the Presidential Candidate Votes According to the Size of the Cities in 1960 (in \%)

\begin{tabular}{|c|c|c|c|}
\hline Cities & $\begin{array}{c}\text { Jânio } \\
\text { Quadros }\end{array}$ & $\begin{array}{l}\text { Henrique } \\
\text { Lott }\end{array}$ & $\begin{array}{l}\text { Adhemar } \\
\text { de Barros }\end{array}$ \\
\hline $\begin{array}{l}\text { Guanabara and } \\
\text { São Paulo City }\end{array}$ & 18.8 & 12.0 & 24.4 \\
\hline Other state capitals & 10.0 & 11.2 & 8.9 \\
\hline $\begin{array}{l}\text { Cities with more } \\
\text { than } 20,000 \text { voters }\end{array}$ & 11.5 & 10.6 & 15.6 \\
\hline $\begin{array}{l}\text { Cities with up to } \\
20,000 \text { voters }\end{array}$ & 60.2 & 66.2 & 51.1 \\
\hline Total & $5,671,528$ & $3,824,258$ & $2,190,609$ \\
\hline
\end{tabular}

Source: Souza (1976, p. 149, chart VI, condensed).

The dependence of all candidates on the small town votes is evident, and this dependence reflects the urbanization standards of the time. Although Barros obtained the fewest votes in the small towns, this was offset by those of the two largest urban centers of Brazil. This compensation obtained from the big cities was due precisely to the candidate's general appeal (populism). It was Quadros, the victorious candidate, who showed a more balanced trend in the distribution of his votes, in proportion to the size of the towns. The voting pattern of that election underlined the break with the hitherto generally accepted interpretation according to which the urban and industrial vote would prevail in a presidential election. This clearly had implications for the then still accepted concept that viewed Brazil's crisis in the early sixties as being exclusively institutional: a modernizing Executive power, due to being rooted in industry and opposed to the more traditional Congress, because of its rural social roots (Furtado, 1969). Contrary to this view, the national basis of the electorate of a 
victorious president finds favorable evidence in the data shown in Table 3.

Additional evidence will be shown for the following hipothesis: over time, the distribution of elected candidates' votes will become less concentrated in certain regions since the socioeconomic differences between these regions decreased. As says Souza, both the votes from the different size cities, and those coming from diverse regions will depend "on the one hand, on a general appeal that go beyond geographical and social frontiers, to begin with the almost total unification of their own state; on the other hand, on the massive conquest through agreements with local governments of other smaller states" (Souza, 1976, p. 148).

The election of Quadros broke a pattern of alliance between the major parties in the presidential elections. A similar election was that of Collor de Mello, who also bypassed the larger parties and important national leaderships. Before examining the regional distribution of votes, I believe we should remember the fact that the presidential election (as from 1960?) has become increasingly intricate. It has begun to reflect Brazil's growing complexity, not only in terms of changing social and economic processes mirrored in the electorate, but also in relation to the political processes, as the federation has begun to more heavily influence the composition of the electorate. Social heterogeneity has become more politically articulate with its diversified social and regional demands.

The articulations aimed at a victorious election required a horizontal movement, bringing parties together, and a vertical approach, including parties and leaders of all three administrative levels. The expansion of suffrage, given its social consequences, the contextual social and economic aspects, the nationalization of the dispute, and the need for a generalized appeal, are today essential conditions for a successful presidential candidacy.

Table 4 shows that the votes for Quadros, fewer than those for Dutra, equal to those for Vargas and more than those for Kubitschek, were evenly distributed through the regions of Brazil, thus sharply differing from prior elections.

More recently, we have seen a reasonable degree of regional distribution in the votes for
Fernando Collor de Mello in the second round of the 1989 elections, and a reasonable degree of homogeneity in the distribution of votes for Fernando Henrique Cardoso in the first round of the 1994 campaign (see Table 5). In the former case, the candidate received $70.5 \%$ of the Northern votes and $63.2 \%$ of the Central-Western votes, in addition to guaranteeing $48 \%$ to $55 \%$ from the remaining regions. Cardoso obtained between $56 \%$ and $60 \%$ of the votes of all regions except the South, where the index was a mere 41.3\% (Nicolau, 1998, pp. 36 and 38). However, neither of these two presidents even approached the almost entirely homogeneous distribution obtained by Quadros in 1960.

Table 4

Regional Source of Votes for

Candidates Elected to the Presidency (\%)

\begin{tabular}{lcccc}
\hline Region & $\begin{array}{c}1945 \\
\text { Dutra }\end{array}$ & $\begin{array}{c}1950 \\
\text { Vargas }\end{array}$ & $\begin{array}{c}1955 \\
\text { Kubitschek }\end{array}$ & $\begin{array}{c}1960 \\
\text { Quadros }\end{array}$ \\
\hline North & 57.2 & 36.3 & 47.3 & 46.5 \\
Northeast & 47.5 & 41.7 & 41.2 & 46.7 \\
Southeast & 54.0 & 53.6 & 32.3 & 48.8 \\
South & 71.3 & 50.5 & 34.6 & 48.7 \\
Central West & 49.0 & 43.4 & 44.6 & 48.6 \\
BRAZIL & 55.3 & 48.7 & 35.7 & 48.3 \\
\hline
\end{tabular}

Source: Lavareda (1991, pp. 175-176).

Table 5

Regional Distribution of Valid Votes: Presidential Elections $(\%)$

\begin{tabular}{lcccccc}
\hline Region & \multicolumn{2}{c}{1989} & \multicolumn{2}{c}{1994} & \multicolumn{2}{c}{1998} \\
& Collor & Lula & FHC & Lula & FHC & Lula \\
\hline North & 70.5 & 29.5 & 58.90 & 25.5 & 57.61 & 26.52 \\
Northeast & 55.7 & 44.3 & 57.60 & 30.3 & 47.73 & 31.64 \\
Southeast & 50.5 & 49.5 & 56.10 & 25.6 & 55.35 & 31.19 \\
South & 48.3 & 51.7 & 41.30 & 28.2 & 49.17 & 38.76 \\
Central West & 63.2 & 36.8 & 60.40 & 24.6 & 61.15 & 22.06 \\
BRAZIL & 53.0 & 47.0 & 54.30 & 27.0 & 53.10 & 31.70 \\
\hline
\end{tabular}

Sources: Jornal do Brasil, 10.11.1998, p. 6, for 1994 and 1998 (first round); Nicolau (1998), for 1994 and 1989; and TSE, IT Secretariat, Internet, for 1998. See note on 1998 data in Table 1.

Fernando Henrique Cardoso was re-elected in 1998 with $4.4 \%$ more votes than those obtained in 1994, although the electorate had grown by $10.7 \%$ over that period. The percentage obtained in total valid votes reached $53.06 \%$, against $54.3 \%$ in 
1994. Both from the absolute and from the relative point of view, Cardoso thus received fewer votes in 1998 than in 1994 . Lula obtained $31.71 \%$ of the valid votes in $1998,4.71 \%$ more than in 1994 . In relative terms, Cardoso lost votes and Lula won them (TSE, IT Secretariat, Internet).

The electoral results of these two elections underscored the different performances of the two main candidates. The votes for Cardoso were relatively greater in only two regions, in the Central-West, and overwhelmingly, in the South (Santa Catarina and Rio Grande do Sul), and lost little in the three other regions. Lula lost votes in the Central-West, obtained significant growth in the Southeast and, mainly, in the South, and advanced little in the other two regions.

After examining the maximum and minimum voting figures for the two candidates, by region, we note that, from the first to the second election, the voting for the elected candidate became more homogeneous between the regions, while the total number of votes decreased in percentage terms. The votes for Lula became less regionally concentrated. For the victorious candidate, these reached $19.1 \%$ (1994) and 11.98\% (1998). The differences in Lula's votes increased from $5.7 \%$ (1994) to $16.7 \%$ (1998).

Unequal distributions are no anomaly in national presidential elections; they merely underline the fact that, in a federation as vast as Brazil's, with its many immense states, and a population unevenly distributed through this huge physical area, the logical and empirically feasible combinations of large and small states, capable of electing a president are incalculable. In the context of society, there is no balance between the social composition of the electorate and its distribution throughout the states.

The electorate has grown steadily, albeit at variable rates between pairs of elections and at decreasing numbers over recent years. The same has occurred with average participation at the polls for the legislative elections of each of the three post 1945 party systems (Lima Junior and Anastasia, 1998).

The voters in the 1989 election numbered $82,056,226$ Brazilians; in 1994, this figure increased to $94,743,043$. Attendance dropped by $85.6 \%$ in 1989 to $82 \%$ in 1994 , and to $78.51 \%$ in 1998 . The percentage of valid votes decreased from the first to the second presidential election from $94.2 \%$ to 81.5\% (Nicolau, 1998, pp. 24 and 26). At Cardoso's re-election, this figure dropped again to $81.3 \%$. In 1989 (second round), the number of absentee, blank, and invalid votes comprised $21.2 \%$ of the electorate. The percentage climbed to $36.6 \%$ in 1994 and, in 1998, soared to a record 40.19\%.

To what degree can recent presidential election data be compared with those of the legislative elections? Under the present party system, attendance at House of Representatives elections has averaged out at $86.2 \%$ for State Congress and $86.3 \%$ for State Assembly elections (Lima Junior and Anastasia, 1998). The results of the three presidential elections show participation figures lower than the legislative election averages for 1982-1994. However, traditionally, valid vote percentages are always bigher in presidential elections than in legislative elections.

The trend is for absentee, blank, and invalid votes to increase throughout the life of a party system, as discussed extensively in a recently published text (Lima Junior and Anastasia, 1998), based on legislative power election data. Although the indices for presidential elections (Table 6) are significantly lower than those for legislative elections, if added to the blank and invalid votes, this total increases for both periods. Invalid votes have increased steadily over the series analyzed and internally in each period. Blank votes do not follow this pattern so strictly: they increased during the most recent period, but represented a significantly lower percentage in the 1955 elections.

The high visibility and centrality of the executive power are basic aspects of our political life and are entirely independent of the political regime. It is my belief that an empirical analysis would show that the executive power, regardless of the system of government in place at the time, would prevail over the legislative power. Throughout our history, under dictatorships the executive power has no competitors. Under democratic or quasi-democratic governments, the executive power is granted privileged treatment both legally 
and in practice and, perhaps for this very reason, has always had more in-depth media coverage. The 1988 Constitution granted the legislative power far wider privileges, but this was also granted to the executive power that, in democratic regimes, had never held the power now granted to it by the Constitution.

Table 6

Electoral Turn-Out, Blank and Invalid Votes 1950 to 1998

\begin{tabular}{|c|c|c|c|c|}
\hline \multirow{3}{*}{$\begin{array}{l}\text { Year } \\
\\
1950\end{array}$} & \multirow{3}{*}{$\begin{array}{c}\text { Turn-Out } \\
8,254,989\end{array}$} & \multirow{2}{*}{\multicolumn{2}{|c|}{$\begin{array}{c}\text { Blank: } \\
N^{\circ} \text { and } \%\end{array}$}} & \multirow{2}{*}{$\begin{array}{c}\text { Invalid: } \\
N^{\circ} \text { and } \%\end{array}$} \\
\hline & & & & \\
\hline & & 211,433 & 2.56 & $145,473 \quad 1.76$ \\
\hline 1955 & $9,097,014$ & 161,852 & 1.77 & $310,185 \quad 3.40$ \\
\hline 1960 & $12,586,354$ & 433,391 & 3.44 & $473,806 \quad 3.76$ \\
\hline $\begin{array}{l}1989 \\
\text { (2nd }\end{array}$ & $\begin{array}{l}70,250,194 \\
\text { und) }\end{array}$ & 986,312 & 1.40 & $3,107,691 \quad 4.40$ \\
\hline 1994 & $77,949,111$ & $7,193,510$ & 9.30 & $7,444,608 \quad 9.60$ \\
\hline 1998 & $83,296,067$ & $6,668,610$ & 8.03 & $8,884,43010.70$ \\
\hline
\end{tabular}

Sources: Porto (1989, pp. 264-266), for 1950 to 1960; Nicolau (1998, pp. 25-28), for 1989 and 1994, and TSE, IT Secretariat, Internet, for 1998. See note on 1998 data in Table 1.

What does the election of Quadros, now so far back in history, have in common with that of Collor and Cardoso in 1994 and 1998, respectively? One primary aspect consists of precisely the argument I made above: as from the election of Quadros, presidential elections have become a national event, based on the dimensions I described earlier. They are no longer a political agreement between half a dozen state oligarchies; no longer can the incumbent select and appoint bis successor; on the contrary, the coalition must be much broader and include the large and small states. Political appeals must disconnect from all that is local and take on a more general, more universal, nature. Furthermore, given the existence and the nature of the federation, including state and local élites, political action must verticalize. The scope of the political network must become as broad as possible, in order to maximize votes. Its growth limit will coincide with the point at which the increase of players represents decreasing electoral returns; in the context of setting up the government, the network should be as small as possible from the point of view of the participating players, so that the "assets" to be divided are individually as great as possible. I do not believe that criteria can be introduced a priori to reconcile these two logical peculiarities. A conceivable solution would be to generate and introduce "new resources" into politics. This increase in volume would lessen the results of its division due to the increase in players.

The above proposition is normative and from a more democratic point of view, has consequences that do not seem very desirable. General election conditions indicate the weakening of the social roots of the parties, the reduction of the differences between them, the need for the formation of formal or informal party alliances and consequently the creation of an unclearly defined network from the ideological and programmatic point of view that, through generalized appeal, could maximize the vote. All these aspects would tend to homogenize the parties and remove their essential distinctions, based on which the voters choose one or another party. These changes produced a new type of party organization known as "catch-all party". Even if different election parties could peacefully live together under one party system, given the prevailing nature of majority elections, particularly of presidential elections, would palpable majority gains accrue to this new organization? Or would it merely strengthen the executive power, particularly by narrowing the party competitiveness within Congress and between this latter and the executive power.

This could lead to the creation of wide-scope political and party ministerial cabinets, should this organization not oppose the proportional party system. This could lead to a democratic gain. This happens with Quadros government that was composed of more parties than any other previous administration in the 1945 Republic, in a stable party context from the point of view of the main participants (Amorim Neto, 1991). The same occurred with the Collor de Mello government and with the first Cardoso government. It has also happened with the second Cardoso government, to judge by the Ministry formed shortly after the president took office. Since Collor de Mello's elec- 
tion had been led by a small and recently formed party, his government strove to create a solid congressional basis of support. Cardoso (19951998), elected by the PSDB-PFL alliance, formed a cabinet that reflected the combination of party forces that elected him, including representatives of the other three parties. It should be borne in mind that his ambitious program of reforms, including constitutional amendments, would require qualified majority for Congress approval. In 1998, the electoral alliance was expanded and the composition of the ministry included its supporting parties, plus the divided PMDB. There is no doubt that the executive power engineered the presence in the second government of these other parties, to ensure its support in Congress.

A further comment is apposite: Quadros was elected by a small party, Collor gained support from a party artificially created to support him and succeeded in overthrowing candidates and political leaders who were members of consolidated party structures. Cardoso was elected in 1994 based on a party alliance of wide-ranging ideology, at least at the time. This happened again in 1998, even though I believe that, at the time of the reelection, the alliance circle had been somewhat reduced, since the PSDB is no longer considered a left wing party.

Could this comparison permit to ascertain the loss of the relative importance of the parties in majority elections and the growing importance of the generalized, broad, and reformist appeal, such as the one I suggested as a vital electoral success factor? Everything points to a yes. This is precisely the situation that at first was opposed: an abortive attempt to govern at the "margin" of the conventional party system. A similar indicator of this hypothetical situation was the 1989 defeat of the major Congress parties. Despite their strength just before the elections, there was little they could do for their candidates to obstruct Collor's rapid ascent. Wouldn't this be Cardoso's situation, elected by the Plano Real?

In the third section, I shall attempt to associate the institutionalized strength of the parties with the results of the election. I believe that the above affirmation stands. No longer does the victory of a presidential campaign depend on the nature of these parties, their different social bases, and their different proposed action plans. Everything points to the fact that the party system is changing. Nothing, as pointed out by Lavareda (1991, ch. 4), indicates that the presidential elections will structure the system as a whole. Everything, in fact, points to the contrary - for the peaceful coexistence of more than one party system in a country of the dimensions and complexity of Brazil. I believe that these systems, both in 1945 (Lima Junior, 1983) and now, change completely from the federal to the state plane (Lima Junior, 1997). There are new differences today, based on differing logical approaches to competition between proportional and majority systems.

Although Lavareda recognizes the prevalence of logic and diverse interests from campaign to campaign, I refer here to logic in its broadest sense. The Burkean general interest seems to be basis of majority compaigns, while specific, local, and sectorial interest would sustain proportional elections. This leads to uncertainty regarding the potential incompatibility between the two powers. Their democratic co-existence, since both enjoy an equal degree of legitimacy, can only be settled in the absence of major changes in politics and by politics.

This also shows that the origin of the conflict between the powers does not arise from differences in the social bases that support them, but in the fact that these are two different forms of representation. Hence the accuracy of Burke's claim that the executive power represents its supporters and its opponents.

\section{The institutional party system: 1989, 1994 and 1998}

At first, the "New Republic's" party system did not represent a total break with the military regime's bi-party system. On the contrary, under the current legislation of the time, the 1982 elections reproduced the two-party system. Later, when more liberal measures were introduced, groups began to break away from the two major parties (MDB and Arena, then called the PMDB and PDS), 
and the left wing parties and other small parties were formed. Some of them even attempted to retain some resemblance to their old parties, such as the PTB, the PDC, the PC do B, the PC, and the PSD. From 1982 to 1998, the number of parties represented in the House of Representatives grew as follows: 5, 19, 19, 18, and 16. In 1982, the two biggest parties held $92.9 \%$ of the seats; in 1998 , this dropped to $43.1 \%$ (Lima Junior, 1995, p. 95).

The 1989 campaign, the first direct presidential election since 1960, brought with it enormous expectations, after the promulgation of the 1988 Constitution, Brazil's charter of democracy. From 1986 to 1988, the party system became more fragmented than ever before in its history. Naturally, the elections mobilized the major parties and nationally respected leaderships. Attendance at the polls, as mentioned earlier, was high. But the election resulted in a humiliating defeat of the consolidated party political forces by a secondary star, Fernando Collor de Mello, hailing from a small and impecunious state, and backed by an equally small party, the PRN, formed exclusively to support his candidacy (Table 7), but who was well received by public opinion.

Table 7

The Pre-Election Parliamentary Party Distribution in 1989 ( $\%$ of seats)

\begin{tabular}{lcc}
\hline Parties & House of Representatives & Senate \\
\hline PMDB & 36.5 & 41.3 \\
PDS & 5.9 & 2.6 \\
PFL & 18.7 & 17.3 \\
PSDB & 10.2 & 13.3 \\
PTB & 3.9 & 5.3 \\
PDT & 5.8 & 4.0 \\
PT & 3.3 & - \\
PCB & 0.6 & - \\
PC do B & 1.2 & - \\
PSB & 1.2 & 2.6 \\
PL & 4.5 & 1.3 \\
PDC & 2.8 & 5.3 \\
PRN & 3.9 & 2.6 \\
Other & 2.4 & 4.0 \\
Total & 494 & 75 \\
\hline
\end{tabular}

Source: Kinzo (1992, p. 22).
High expectations created in presidential campaigns are hardly a novelty. Kubitschek promised to deliver, within five years, a degree of development of Brazil that would only be possible in fifty years. Quadros arrived promising to transform everything. Collor promised instant entry into the First World. To a certain extent, Cardoso's promises suggested a combination of Kubitschek and Collor. Grandiose reform projects allied to personality traits are characteristics of the presidencialism (Jones, 1995; Linz and Valenzuela, 1994; Lijphart, 1992); they are the means whereby a president reinforces his authority legitimacy before Congress and the people. Strong and generalized appeals are the standard ingredients for electoral victory. The more consensual the proposals, the less the resistance of the different sectors of the population.

If the political mobilization factor, the enthusiasm for incipient democracy dominated the 1989 pre-electoral scenario, it was the performance of the economy, the Plano Real generating monetary stability that predominated in the 1994 campaign. What do these two factors have in common? Nothing, apparently, but I believe that the combination of changeism and daring proposals were the common denominator that are such important factors in popular psychology, particularly in the context of an underdeveloped country, where almost everything has still to be done. Kubitschek and his Plano de Metas, Quadros and his ascetic nationalism are recurring memories and models.

The PRN was merely a microparty in the 1989 legislature; the only party of any national weight was the PMDB of Ulysses Guimarães, "Dr. Constitution" who, together with other nationally known leaders, Covas, Maluf, and Brizola, was defeated by a young politician from Alagoas. Lula passed into the second round and Collor won by a $6 \%$ vote difference, nearly four million voters (Nicolau, 1998). What counted greatly in his favor, in addition to his daring proposal for reform and a break with the past, was his youth and a technically well run election campaign, to judge from the acknowledgment obtained from professionals in this area.

By 1994, the party system (Table 8) was further fragmented, due less to the number of parties and more to the relative distribution of seats 
in Congress, as a result of the weakened condition of the PMDB. Once again, the more consolidated parties and their machinery had no fundamental impact. Lula and Brizola tried again; Quércia became the PMDB candidate; Fernando Henrique Cardoso and Marco Maciel were candidates for the PSDB-PFL. So, on the one hand, we had the PMDB, a still reputable party, supporting Quércia and, on the other hand, a party of similar proportions, the PFL, supporting Fernando Henrique Cardoso and providing him with a vice-president. No second round was needed.

Table 8

The Pre-Electoral Parliamentary Party Distribution in 1994 (\% of chairs)

\begin{tabular}{lcc}
\hline Parties & House & Senate \\
\hline PMDB & 20.8 & 27.2 \\
PFL & 17.3 & 21.0 \\
PDS & 10.1 & 8.6 \\
PSDB & 12.3 & 13.6 \\
PDT & 6.4 & 7.4 \\
PTB & 6.2 & 6.2 \\
PT & 9.5 & 6.2 \\
PP & 7.0 & 6.2 \\
PL & 2.5 & 1.2 \\
PSB & 2.9 & 1.2 \\
PC do B & 2.0 & - \\
PPS & - & 1.2 \\
Other & 2.8 & - \\
\hline
\end{tabular}

Source: Lima Junior (1995, pp. 95-96, charts 3 and 4).

This alliance, hitherto viewed as being of the center-right, defeated the left wing PT (worker's party) candidate. Cardoso obtained $54.3 \%$ of the total votes and the runner up, Lula, a mere $27 \%$ (Nicolau, 1998). The victory could in no way be attributed to the PSDB-PFL alliance, although, admittedly, institutionally it had a respectable national base. Nevertheless, regardless of the performance of all the politicians linked to it, this did not guarantee the election. As we all know, the critical and determining factor was the launching and immediate success of the Plano Real, in addition to the ambitious "All Hands to the Wheel, Brazil!" project.
In 1998 the party system was more concentrated than it had been in 1994, although the number of parties in the House of Representatives had increased. The number of parties in the Senate dropped from eleven to five. If we consider the joint relative force of the two largest parties in these three legislatures (PMDB and PFL in the first two, and the PFL and PSDB in the third), we arrive at the following percentages in the House and in the Senate, respectively: $55.2 \%$ and $58.6 \%$ in 1989 ; $38.1 \%$ and $48.2 \%$ in 1994 ; and $40.3 \%$ and $55.4 \%$ in 1989 (Tables 7, 8, and 9).

Table 9

The Pre-Electoral Parliamentary Party Distribution in 1998 (\% of chairs)

\begin{tabular}{lcc}
\hline Parties & House & Senate \\
\hline PFL & 21.4 & 29.6 \\
PSDB & 18.9 & 25.9 \\
PMDB & 16.7 & 17.3 \\
PPB & 15.4 & 8.6 \\
PT & 9.7 & 6.1 \\
PDT & 4.3 & 4.9 \\
PTB & 4.3 & 3.7 \\
PSB & 2.7 & 2.4 \\
PL & 0.2 & - \\
PC do B & 0.2 & - \\
PPS & 0.1 & 1.2 \\
PSD & 0.05 & - \\
PRONA & 0.01 & - \\
PMN & 0.01 & - \\
PV & 0.01 & - \\
PSTU & 0.01 & - \\
Total & 513 & 81 \\
\hline
\end{tabular}

Source: General Table Secretariat and IT Nucleus of the House of Representatives, and General Table Secretariat of the Senate, data published by the Folha de S. Paulo, 2.5.1998.

In order to be put into action, the wide scope and ambition of the Collor de Mello government plans and even more important, those of the Cardoso government, required massive public opinion support. This need for public approval was based on the premise that the general public had understood the depth of the proposed reforms and remembered them even if, at the time, these re- 
forms had been significantly curtailed. They also required solid Congress support. Both presidents struggled to deliver. Collor abandoned the effort to obtain this support early due to his impeachment that was strongly supported by the people. Fernando Henrique Cardoso at first succeeded in obtaining a party support base in Congress, one far broader than Collor's, theoretically involving five parties. However, the maintenance of this support that the president always hoped would be automatic, fluctuated from issue to issue, and its party composition varied wildly. Essentially, the government obtained Congress approval of the majority of the measures deemed essential, perhaps for the first time in the history of the Republic.

And so, the government challenged established interests and ceased to foster other interests. Since, for the first time, the principle of re-election was in force, 1998 will be an excellent opportunity to put to the test the plausibility of the set of suppositions described above. This point must be covered in greater detail.

Throughout his term of office, president Cardoso demanded Congress approval of the constitutional or infra-constitutional reforms he sent in. This was justified as being in the national interest, and based on the wishes of the people: he had been elected to carry out reforms in the interest of the people, against privilege, undue benefits, and clientelism. I believe that, independently of Congress' reaction, the true content of this renewed general appeal, the same as that made during the election campaign, must comply with three basic prerequisites: firstly, the specific nature of the reforms should have been put clearly to the people; secondly, the people should have understood these proposals equally clearly, and accepted them as such; thirdly, the reforms proposed by the government should have been those that were put to and approved by public opinion during the campaign. Several other aspects further undermined this approval, starting with the fact that the request for approval violated one of the essential conditions, as we can see, for a presidential candidature to obtain full electoral success: generic and neutral appeals from the point of view of potential social and economic conflict.
The Plano Real, already in action during the campaign, embodied all these features, but this did not apply to the other reforms proposed by the government that, on moving from rhetoric to fact, especially in the form of proposed constitutional amendments, revealed a high conflict potential. They also implied costs in the short term impacting a large percentage of the population. This is the context in which to understand the reactions of Congress to the present government's reform proposals. In this context, the argument that what really put Cardoso in office was the Plano Real, not the "All Hands to the Wheel, Brazil!" and most certainly not the stronger version later given by the government is reinforced.

On the eve of the close of the 1998 election campaign, faced with the huge pressure arising from the international financial crisis, the presidential candidate announced that, if he were reelected, he would take drastic measures to defend the national currency, for which he would not discard the possibility of levying or increasing taxes. He was re-elected in the first election round by a wide voting margin.

It is my belief that the central problem to exercising the Presidency in Brazil is not the institution of presidentialism associated with federalism and the proportional election system (Lijphart, 1992; Jones, 1995; Mainwaring and Scully, 1995; Mainwaring and Shugart, 1997). It lies in the personalist nature of the exercising of the Presidency. This was already manifested during the election period as an essential condition for victory and consists of the formulation of government proposals that are, $a$ priori, impracticable, since they exceed the installed capacity of the existing political processing system.

Goulart's reforming impulse can be compared with that of Cardoso; the basic difference is that Cardoso's proposals are less ideologically radical (to the left, naturally) and more attuned to what seems to be a leader's interpretation of the major transformations in the contemporary world. Thus, it is understandable why the resistance to the reforms proposed by Goulart sent him into exile, while Cardoso is awarded a succession of honorary degrees.

It would be interesting to conclude this section with a reflection on the institution of re- 
election and on the interpretation given to Brazil's most recent municipal elections. In this case, if I am not mistaken, the success of mayors who nominated their successors is due to their administrative achievements. Will this same principle be valid in the 1998 presidential election? In other words, will this have been a plebiscite, a judgment of Cardoso's performance as president?

\section{Voting intention and the social bases in presidential elections (1994 and 1998)}

Essentially this matter is equivalent to checking whether the Plano Real political support (its most visible impact for the population was the sharp drop and control of inflation at very low percentages) would have survived to guarantee Fernando Henrique Cardoso a second term of Presidency, independently of any other adverse internal or external factors. This is a very strong proposition since it eliminates circumstantial factors, presupposes the unaltered maintenance of the president's positive image, and ignores the electoral context of the dispute, i.e., the relative force of the other candidates.

It is plausible to accept the central role of the Plano Real in controlling inflation. This can be seen, in the absence of any decline in the presidential image, as a necessary condition for re-election. Today we know that the government was extremely cautious, and avoided any measure, announcement or economic decision that could mar the president's image. Concepts of continuity and of good management to be centered in the "Brazil in Action" program were carefully drawn up. Nevertheless, I believe that this is not enough, and would not be sufficient for Cardoso's re-election. In the absence of a specific survey, other less direct indicators should be applied to introduce specific electoral context data to discuss the matter. I believe that the indicators that are followed, of vote intentions, produced by opinion polls organizations, would aid in clarifying the problem, at least in terms of correlation of political forces, and their evolution throughout the election campaign between the two most popular and, in the end, most voted candidates (Tables 10 and 11).
Table 10

\begin{tabular}{|c|c|c|c|c|c|}
\hline \multicolumn{6}{|c|}{$\begin{array}{l}\text { Change in Voting Intention for the } \\
\text { Presidential Candidates in } 1994\end{array}$} \\
\hline \multicolumn{2}{|c|}{$\begin{array}{l}\text { DataFolha } \\
\text { May } 29\end{array}$} & \multicolumn{2}{|c|}{$\begin{array}{c}\text { Vox Populi } \\
\text { July } 30\end{array}$} & \multicolumn{2}{|c|}{$\begin{array}{c}\text { Vox Populi } \\
\text { October } 3\end{array}$} \\
\hline Lula & Cardoso & Lula & Cardoso & Lula & Cardoso \\
\hline 40 & 17 & 30 & 29 & 21 & 39 \\
\hline
\end{tabular}

Source: Lima Junior (1995, p. 100).

Table 11

Change in Voting Intention for the Presidential Candidates in 1998

\begin{tabular}{lcccc}
\hline Month & \multicolumn{2}{c}{ DataFolha } & \multicolumn{2}{c}{ IstoÉ } \\
\hline \multirow{3}{*}{ May } & Cardoso & Lula & Cardoso & Lula \\
July & 34 & 30 & 33 & 26 \\
September & 40 & 28 & 40 & 27 \\
\hline
\end{tabular}

Sources: DataFolha, Folha de S. Paulo (9.27.1998, p. 3); surveys carried out on May 27 and 28; July 8 and 9; and September 17 and 18. IstoÉ/Brasmarketing/SBT, IstoÉ (9.23.1998); surveys carried out on May 28, July 30, and September 17.

According to the IBOPE polls (Jornal do Brasil, 9.4.1998), Cardoso obtained the following percentages: $33 \%, 40 \%$, and 44\%, the last representing the figure for late August. The data from the three institutes on dates close to one another are very consistent. Furthermore, they all point to the same trend: the growth of Cardoso's candidature and the drop in Lula's. This distance is also growing between them, according to the DataFolha, while Isto $E$ shows a slight drop between the second and third counts (only from 13\% to 11\%) for Lula.

In May 1998, Luiz Inácio Lula da Silva, who in May 1994 held 45\% of the intended votes, obtained only a 30\% preference. His candidature in 1998 was weak, as was Cardoso's. The latter, however, during the 1994 campaign, benefited from highly favorable factors. As we know, the huge turnaround in Cardoso's favor came about with the introduction and launching of the Plano Real. The control of inflation, that the opposition forces at first viewed as an "election maneuver", was and is an easily comprehended policy, due to its single dimension nature (the size of inflation). Antiinflationary policy obtained immediate results and had a quasi-universal and unequivocal impact (Lima and Lima Junior, 1997). 
Figure 1 clearly shows the distance between of the two candidates throughout the 1998 campaign. The argument was split into two basic conditions that guaranteed Cardoso's victory: administrative performance whose flagship was the success of the Real, and the relative weakness of his principal opponent. Other positive aspects also contributed to Cardoso's candidature, in addition to some negative points that reduced the force of the opposition candidate, for which however, no strong evidence exists: the role of the media, élitism, and prejudice against a former worker as president of Brazil, the fear that there would be a huge drain of foreign capital and even local capital.

In its analysis of the growth of the president's prestige during his first term of office, the São Paulo newspaper, Folha de S. Paulo (12.7.1998, p. 4), shows that the average grade given to government performance has fluctuated little (from 5.4 to 6.5), despite the fact that, on the eve of the election (September 24 and 25) a public opinion poll showed a drop in the evaluation of president Cardoso. Just prior to the election, Renato Janine Ribeiro (1998) brilliantly summarized the factors that, hard as they were to evaluate and measure, positively impacted a candidate:

We have the person of the candidate and of the president. The person of the president so strongly impacts public opinion, that it is difficult to set aside a space where he is merely a candidate. It is hard to put him on the same level as the other candidates. He is symbolically too unequal. He is the Head of the State and the representative of our country. We respect the person who is in power. (stoÉ, 9.30.1998, p. 9)

The indicators shown in Tables 12 and 13 reinforce the interpretation I have given on the

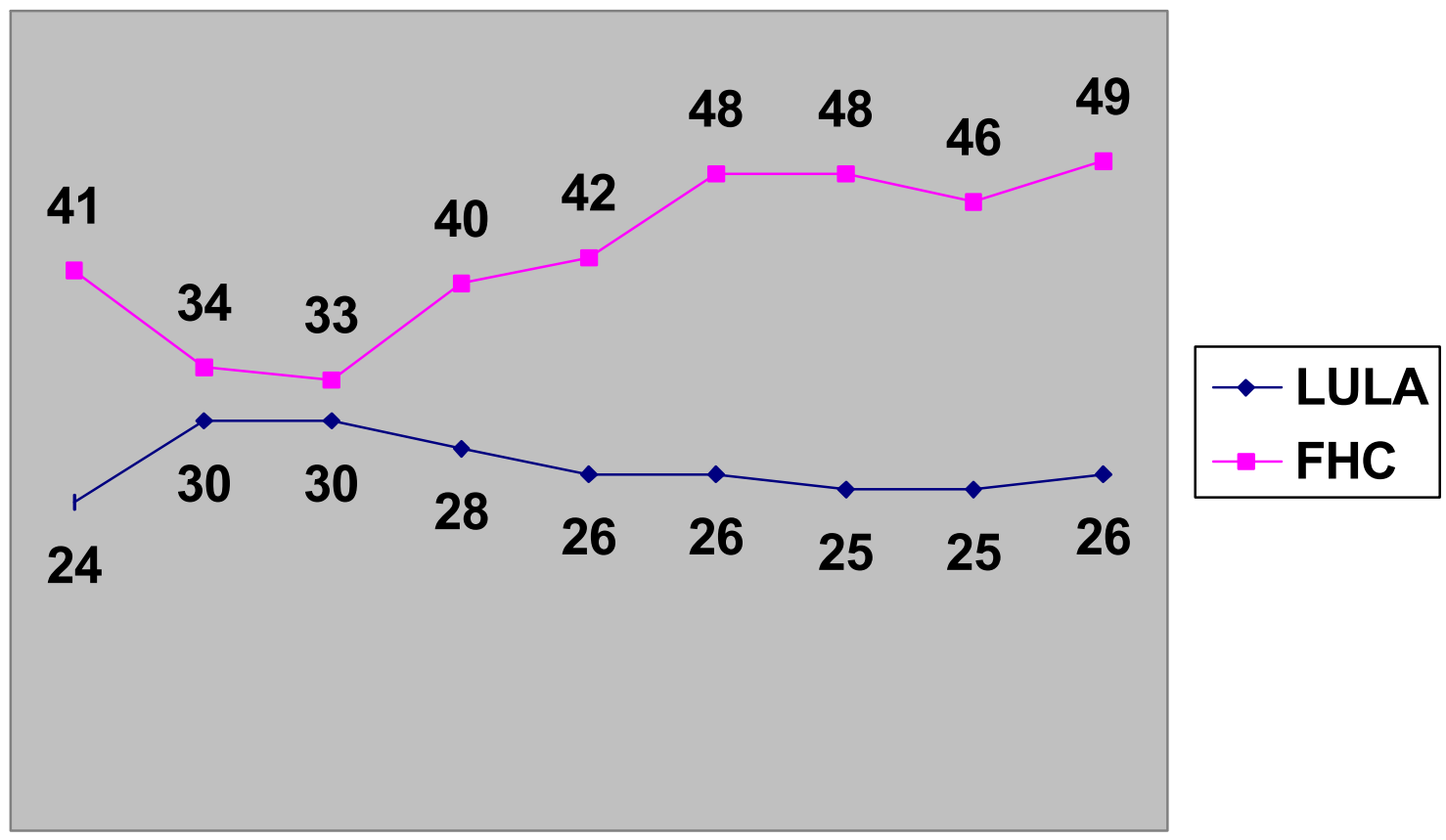

Figure 1

Voting Intention for the Presidential Candidates April-September 1998

Sources: DataFolha, Folha de S. Paulo, September 27,1998, p. 3; surveys carried out on April 29 and 30, 1998; May 27 and 28; June 8 and 9; July 8 and 9; August 12 to 14; September 1 and 2, 17 and 18, and 24 and 25. Folha de S. Paulo, 10.4.1998, p. 3 , for the most recent data (10.2.1998). 
national character of presidential elections, despite the weight I have attributed to political and circumstantial factors in an explanation that I believe is more of a structural and social nature.

The "region" factor shows that when Lula and Cardoso capitalize on the voting intent (on May 29 and October 3), they do this in all regions and the percentage differences are high, except in the South. When, however, the candidates find themselves at a technical tie, despite each one's penetration being variable, the differences by region, between them, are considerably less. The averages of these differences are $23 \%$ and $23.2 \%$ for the times when one of them is greatly in favor, but this figure drops to $6.2 \%$ when there is a technical tie.

The same trend applies when the age factor is analyzed: if there is majority candidate, he holds the majority for all age groups, and the difference between the candidates increases. If there is no majority candidate but a technical tie instead, the differences drop sharply. In the first case the figures are $19.8 \%$ and $20.8 \%$; in the second case, they drop to $8.4 \%$. Although the majority candidate will win at all age levels, a certain favoritism benefits Cardoso's candidature at the higher levels, and Lula at the lower levels, even in a technical impasse.

Lastly, the "income" indicator bears out the general interpretation. When one candidate holds the majority of the vote intentions, the differences are $16.6 \%$ and $20.2 \%$, which drop to $6 \%$ in a technical tie. Income, like age, allows for differentiation in candidate preference; the candidate who holds the majority wins at all levels of income, but the higher the income level, the great-
Table 12

Voting Intention According to

Selected Indicators (1994)

\begin{tabular}{|c|c|c|c|c|c|c|}
\hline \multirow[t]{2}{*}{ Indicator } & \multicolumn{2}{|c|}{ DataFolba } & \multicolumn{2}{|c|}{ Vox Populi } & \multicolumn{2}{|c|}{ Vox Populi } \\
\hline & Lula & $F H C$ & Lula & $F H C$ & Lula & $\overline{F H C}$ \\
\hline Region & & & & & & \\
\hline $\mathrm{NO}-\mathrm{CO}$ & 38 & 19 & & & & \\
\hline NO & & & 26 & 28 & 17 & 52 \\
\hline $\mathrm{CO}$ & & & 28 & 37 & 23 & 54 \\
\hline $\mathrm{NE}$ & 43 & 15 & 36 & 25 & 27 & 48 \\
\hline SE & 38 & 20 & 28 & 32 & 24 & 45 \\
\hline$\overline{A g e}$ & & & & & & \\
\hline $16-24$ & 49 & 17 & 40 & 25 & 26 & 44 \\
\hline $25-29$ & & & 31 & 25 & 32 & 39 \\
\hline $25-34$ & 42 & 16 & & & & \\
\hline $30-39$ & & & 28 & 29 & 27 & 43 \\
\hline $35-44$ & 40 & 16 & & & & \\
\hline $40-49$ & & & 24 & 33 & 19 & 48 \\
\hline $45-49$ & 32 & 18 & & & & \\
\hline 50 and over & & & 23 & 34 & 17 & 51 \\
\hline 69 and over & 24 & 21 & & & & \\
\hline Education & & & & & & \\
\hline A & 40 & 14 & 29 & 27 & 20 & 47 \\
\hline B & 38 & 25 & 33 & 28 & 25 & 46 \\
\hline$\underline{\mathrm{C}}$ & 42 & 23 & 28 & 33 & 29 & 42 \\
\hline Income & & & & & & \\
\hline Up to $1 \mathrm{MW}$ & & & 32 & 24 & 23 & 45 \\
\hline 1 to $5 \mathrm{MW}$ & & & 31 & 27 & 24 & 44 \\
\hline Up to $5 \mathrm{MW}$ & 41 & 15 & & & & \\
\hline 5 to $10 \mathrm{MW}$ & 39 & 24 & 27 & 34 & 27 & 44 \\
\hline Over $10 \mathrm{MW}$ & 35 & 26 & 25 & 37 & 26 & 48 \\
\hline Voting intention & 240 & 17 & 30 & 29 & 21 & 39 \\
\hline
\end{tabular}

Sources: DataFolha, Folha de S. Paulo, 5.29.1994; Vox Populi, Jornal do Brasil, 7.30.1994 and 10.3.1994.
Table 13

Voting Intention According to Selected Indicators (1998)

\begin{tabular}{cccc}
\hline Indicator & \multicolumn{2}{c}{ DataFolha } & IBOPE \\
September 24 and 25 & May 10 to 13 \\
\hline FHC & Lula & FHC & Lula
\end{tabular}

Age

$\begin{array}{lllll}16-24 & 47 & 29 & 43 & 27\end{array}$

25-39

25-34

$35-48$

35-44

50 or over

45-59

- -29

27

$\begin{array}{llll}46 & 26 & 40 & 24\end{array}$

- $\quad-\quad 36 \quad 24$

60 or over

$45 \quad 26$

39

19

Education

Elementary School $47 \quad 24 \quad$ -

(incomplete)

Elementary School —- $\quad$ - $\quad 43 \quad 36$

High School —- — $\quad$ - $\quad 36 \quad 28$

(incomplete)

$\begin{array}{lllll}\text { High School } & 46 & 25 & 37 & 23\end{array}$

College (incomplete) - $\quad$ - $\quad 39 \quad 23$

College

Income

Up to $10 \mathrm{MW} \quad 45 \quad 25$

10 to $20 \mathrm{MW} \quad 50 \quad 23$

Over $20 \mathrm{MW} \quad 53 \quad 25$

Sources: DataFolha, Folha de S. Paulo, 9.27.1998, p. 3; IBOPE, Jornal do Brasil, 5.23.1998, p. 3. 
er the probability of Cardoso winning more votes. An analysis of these indicators, in conjunction with the argument I have been developing, allows me to state that the presidential election has effectively been transformed into a national event. This is based on the aspects set forth above and, now, on the heterogeneous social factor of the electorate as an essential condition for a presidential election victory.

The set of evidences presented, based on political, demographic, and social structure indicators, show the nationalization of the presidential election. Given its position in a strong executive presidential system, the presidential election is a vital factor in the political integration process, which cannot be summarized as nationalization as treated herein. The election may, however, in the medium term, positively impact the restructuring of the party system.

\section{The nationalization and centrality of the presidential elections}

Cardoso's election in 1994, in the first round, was vital to the growth of the PSDB at the level of executive election. The party that, in the first round, elected only the governor of the State of São Paulo, in the second raised five more governors to power. During that period, the PSDB was only surpassed by the PMDB, which elected a total of nine governors in the two rounds. In 1998, in addition to Cardoso, three governors were elected by the PSDB (Ceará, Espírito Santo, and Mato Grosso); in the second round, the party elected a further four (Pará, Goiás, São Paulo, and Sergipe). The political strength, at this level, of the party and the presidential leadership did not change from 1994 to 1998.

The central argument of this article is to accentuate the unique feature acquired by Brazilian presidential elections, as from Jânio Quadros, which I condensed into the term nationalization of the election campaign. This nationalization is recent. The main aspects of the process are varied: geography, social and economic aspects, and politics. In association, these different dimensions reveal an aspect frequently neglected in Brazilian politics analyses: the progressive political integration of the country.

Geographically speaking a successful candidacy requires a majority vote in a combination of states comprising the large and the small electorates. This combination can vary greatly, as shown by Santos $(1987$, ch. V) in his analysis of the period comprising 1945-1964 from the political representation point of view. Densely populated and economically strong states no longer dominate the elections. The urban-rural disparity cannot account for a victorious presidential candidacy. This territorial scope arises from the growth and deconcentration of the Brazilian electorate over the last 30 or 40 years. This, in turn, is the outcome of a combination of changes in Brazilian society and politics, such as the population growth, internal migrations, and the disappearance of legal impediments to political participation.

Seen from a social and economic point of view, the central dimension is related to the social heterogeneity of the support bases for a victorious presidential candidate. The complexity of the Brazilian social structure is such that it is no longer possible for specific coalitions with strong social and economic affinities to define the directions of a campaign and, consequently, support a victorious candidature. The victorious candidate is supported by an inclusive social base, somewhat amourphous, with a widespread popular or mass appeal, regardless of the existence of social differences between the candidates.

Politically speaking, several indicators integrate this view of universalized presidential elections. Firstly, the size of the electorate and the variety of preferences it expresses, require collective political action that, metaphorically, I described as vertical and horizontal. In the first case, to emphasize the support alliance requires a plausible candidate to advance in the direction of the lower levels of the federation, involving parties and leaderships in the states and municipalities. In the second case, in the absence of any major parties, the creation of a party alliance whose size and limits could generate serious consequences for subsequently exercising government. Still from the political viewpoint, the tone of a presidential cam- 
paign must be based on a generalized appeal that maximizes the consensus and, preferably, suggests government actions such as growth, expansion, generalized gains, and minimal losses.

\section{REFERENCES}

AMORIM NETO, Octávio. (1991), Formação Ministerial em Sistemas Presidencialistas Multipartidários: O Caso Brasileiro, 1946-1965. Rio de Janeiro, Master degree dissertation in Political Science, Iuperj.

BARBOZA FILHO, Rubem. (1995), "A Desdramatização da Mudança ou o 'Desencantamento' do Brasil". Dados, 38, 1: 145-162.

CARVALHO, José Murilo de. (1990), "Sistemas Eleitorais e Partidos no Império", in Olavo Brasil de Lima Junior (ed.), O Balanço do Poder, Rio de Janeiro, Rio Fundo/Iuperj, p. 17.

DAHL, Robert. (1997 [1972]), Poliarquia. Participação e Oposição. São Paulo, Edusp.

FERNANDES, Luís. (1995), "Muito Barulho por Nada? O Realinhamento Político Ideológico nas Eleições de 1994". Dados, 35, 1: 107-144.

FURTADO, Celso. (1969), "Political Obstacles to Economic Growth in Brazil", in Carlos Veliz (ed.), Obstacles to Change in Latin America, Oxford, Oxford University Press.

JONES, Mark P. (1995), Electoral Laws and the Survival of Presidential Democracies. Notre Dame, University of Notre Dame Press.

KINZO, Maria d'Alva Gil. (1992), "A Eleição Presidencial de 1989: O Comportamento Eleitoral em uma Cidade Brasileira”. Dados, 35, 1: 49-66.

LANE, Jan-Erik. (1996), Constitutions and Political Theory. Manchester/New York, Manchester University Press.

LAVAREDA, Antônio. (1991), A Democracia nas Urnas. O Processo Partidário Eleitoral Brasileiro. Rio de Janeiro, Iuperj/Rio Fundo.

LIJPHART, Arend (ed.). (1992), Parliamentary versus Presidential Government. Oxford, Oxford University Press.

LIMA JUNIOR, Olavo Brasil de. (1983), Partidos Politicos Brasileiros: A Experiência Federale Regional, 1945/64. Rio de Janeiro, Graal. (ed.). (1990), O Balanço do Poder. Rio de Janeiro, Rio Fundo/Iuperj.

(1995), "As Eleições de 1994: Resultados e Implicações Político-Institucionais". Dados, 35, 1: 93-106.

(1997), Instituições Políticas Democráticas. O Segredo da Legitimidade. Rio de Janeiro, Jorge Zahar Ed.

(1998), "As Reformas Administrativas no Brasil: Modelos, Sucessos e Fracassos". Revista do Serviço Público, ano 49, 2, abr.-jun.

LIMA JUNIOR, Olavo Brasil de and ANASTASIA, Maria de Fátima Junho. (1998), "A Participação Política: A Ampliação do Mercado Eleitoral e as Distorções do Sistema de Representação". Paper presented at the XXII Encontro Anual da Anpocs, Caxambu, MG, October.

LIMA JUNIOR, Olavo Brasil de; VALENÇA, Rachel Teixeira and ARAÚJO, Rosa Maria (eds.). (1991), Sucessão e Posse na República, 18891989. Rio de Janeiro/Brasília, Fundação Casa de Rui Barbosa/Senado Federal.

LIMA, Maria Regina Soares de and LIMA JUNIOR, Olavo Brasil de. (1997), "A Política das Reformas Constitucionais: Contexto, Percepção das Elites Políticas, Resultados Antecipados e Atores". Paper presented at the XXI Encontro Anual da Anpocs, Caxambu, MG, October.

LINZ, Juan and VALENZUELA, Arturo (eds.). (1994), The Failure of Presidential Democracy. Baltimore, The Johns Hopkins University Press.

MAINWARING, Scott and SCULLY, Timothy (eds.). (1995), Building Democratic Institutions: Party Systems in Latin America. Stanford, Stanford University Press.

MAINWARING, Scott and SHUGART, Matthew Sobert. (1997), Presidentialism and Democracy in Latin America. Cambridge, Cambridge University Press.

MICHEL, Renault and RANGEL, Ronaldo. (1995), "Eleitor, um Ser Já Não Tão Desconhecido". Monitor Público, n. 5, year 2, March-May: 7-13.

NICOLAU, Jairo Marconi (ed.). (1998), Dados Eleitorais do Brasil (1982-1990). Rio de Janeiro, Iuperj/Revan.

PORTO, Walter Costa. (1989), O Voto no Brasil: Da Colônia à Quinta República. Brasília, Senado Federal. 
RIBEIRO, Renato Janine. (1998), "Democracia Desfocada". Interview to the magazine Isto É, n. 1.530, September 30.

RODRIGUES, Leôncio Martins. (1995), "As Eleições de 1994: Uma Apreciação Geral”. Dados, 35, 1: 7192.

SANTOS, Wanderley Guilherme dos. (1987), Crise e Castigo. Partidos e Generais na Política Brasileira. Rio de Janeiro, Iuperj/Vértice.

SANTOS, Wanderley Guilherme dos and SCHMITT, Rogério. (1995), "Dois Fernando, uma Eleição". Monitor Público, n. 4, year 2, Dec.-Feb.: 53-58.

SOUZA, Maria do Carmo Campello de. (1976), Estado e Partidos Políticos no Brasil (1930-1964). São Paulo, Alfa-Ômega.

TAVARES, José Giusti. (1995), "O Ciclo Eleitoral no Presidencialismo Proporcionalista". Monitor Público, n. 7, year 2, Sept.-Nov.: 27-34. 